\title{
Selective Inhibition of Syncytium-inducing and Nonsyncytium-inducing HIV-1 Variants in Individuals Receiving Didanosine or Zidovudine, Respectively
}

\author{
Angélique B. van 't Wout, ${ }^{\star}$ Leonie J. Ran, ${ }^{\star}$ Menno D. de Jong, ${ }^{\ddagger}$ Margreet Bakker, ${ }^{\S}$ Remko van Leeuwen, ${ }^{\ddagger}$ Daan W. Notermans, ${ }^{\ddagger}$ \\ A. Edde Loeliger, ${ }^{\ddagger}$ Frank de Wolf, ${ }^{\S}$ Sven A. Danner, ${ }^{\ddagger}$ Peter Reiss, ${ }^{\ddagger}$ Charles A.B. Boucher, ${ }^{\|}$Joep M.A. Lange, ${ }^{\ddagger}$ \\ and Hanneke Schuitemaker* \\ *Department of Clinical Viro-Immunology, Central Laboratory of the Netherlands Red Cross Blood Transfusion Service and the \\ Laboratory of Experimental and Clinical Immunology of the University of Amsterdam, 1066 CX, Amsterdam, The Netherlands; ${ }^{\circ}$ National \\ AIDS Therapy Evaluation Centre and Division of Infectious Diseases, Tropical Medicine \& AIDS, Department of Internal Medicine, \\ Academic Medical Centre, University of Amsterdam, 1105 AZ, Amsterdam, The Netherlands; ${ }^{\S}$ Department of Human Retro-Virology,

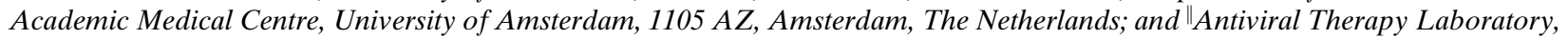 \\ Department of Virology, Academic Medical Centre, University of Amsterdam, 1105 AZ, Amsterdam, The Netherlands
}

\begin{abstract}
By studying changes in the clonal composition of HIV-1 populations during the first weeks of zidovudine (ZDV) treatment before the development of $\mathrm{ZDV}$ resistance-conferring mutations, we demonstrated previously a selective inhibition of nonsyncytium-inducing (NSI) HIV-1, even when present as coexisting population in individuals also harboring syncytium-inducing (SI) HIV-1. In this study, we observed the opposite in individuals receiving didanosine (ddI) treatment. In these individuals $(n=7)$ a median $\mathbf{- 0 . 9 8}$ log change (range $-1.55-0.08$ ) in infectious cellular SI load was observed, whereas the coexisting NSI load was only minimally affected (median $-0.15 \mathrm{log}$, range $-1.27-$ $0.50 ; P=0.03$ ). The virus phenotype-dependent treatment responses were independent of the clonal composition of HIV-1 populations at baseline. Individuals treated with a combination of $\mathrm{ZDV}$ and ddI revealed an equal decline of both NSI and SI infectious cellular load ( $n=4$; NSI: median -1.55 log, range -2.19 to -1.45 ; SI: median -1.47 log, range -1.81 to $-0.86 ; P=0.56$ ).

To test the hypothesis that the previously reported optimal activation of $\mathrm{ZDV}$ and ddI in activated and resting $\mathrm{T}$
\end{abstract}

Presented in part at: The Fifth International HIV Drug Resistance Workshop, July 1996, Whistler, Canada; The Second Consensus Symposium on Combined Antiviral Therapy, September 1996, Barcelona, Spain; and The Fourth Conference on Retroviruses and Opportunistic Infections, January 1997, Washington DC.

Address correspondence to Hanneke Schuitemaker, Department of Clinical Viro-Immunology, Central Laboratory of the Netherlands Red Cross Blood Transfusion Service, Plesmanlaan 125, 1066 CX, Amsterdam, The Netherlands. Phone: 31-20-5123110/5123317; FAX: 31-20-5123310. Menno D. de Jong's present address is Department of Medical Microbiology, University of Amsterdam, Academic Medical Centre, 1105 AZ, Amsterdam, The Netherlands; A. Edde Loeliger's present address is Viral Diseases, GlaxoWellcome, Research Triangle Park, North Carolina 27709; Charles A.B. Boucher's present address is Department of Virology, Eykman-Winkler Institute, University Hospital Utrecht, 3584 CX, Utrecht, The Netherlands.

Received for publication 7 February 1997 and accepted in revised form 24 August 1997.

J. Clin. Invest.

(C) The American Society for Clinical Investigation, Inc. 0021-9738/97/11/2325/08 \$2.00

Volume 100, Number 9, November 1997, 2325-2332

http://www.jci.org cells, respectively, in combination with the differential $\mathrm{T}$ cell tropism of NSI and SI HIV-1 is the basis for the observed virus phenotype specific efficacy of nucleoside analogs, we studied the effect of treatment with a protease inhibitor that does not require intracellular activation. Individuals receiving ritonavir $(n=4)$ indeed showed equal declines in NSI and SI infectious cellular load (NSI: median $-2.37 \mathrm{log}$, range -2.59 to -2.16 ; SI: median $-2.82 \log$, range -3.14 to $-2.50 ; P=0.25)$. Our data suggest HIV-1 phenotype as an additional parameter in the design of optimal treatment regimens. (J. Clin. Invest. 1997. 100:2325-2332.) Key words: HIV-1 biological phenotype • anti-retroviral therapy • AIDS • cell cycle dependency $\bullet$ ritonavir

\section{Introduction}

The biological properties of the HIV-1, such as replication rate, cell tropism, and cytopathicity, can vary in the course of HIV-1 infection (1-4). In the early asymptomatic phase preferentially macrophage-tropic, nonsyncytium-inducing (NSI) $)^{1}$ variants predominate, whereas in the course of the infection more $\mathrm{T}$ cell tropic variants appear, in $50 \%$ of cases associated with the emergence of syncytium-inducing (SI) variants (5-8). Recently, it has been shown that HIV-1 tropism is mainly determined by second receptor usage. Macrophagetropic NSI variants use the $\beta$ chemokine receptor-5 (CCR5), T cell line tropic SI variants use the $\alpha$ chemokine receptor- 4 (CXCR4), and primary SI variants can use both (9-16). Based on chemokine responsiveness of PBMC, CXCR4 is thought to be expressed abundantly, while CCR5 expression on PBMC is low $(17,18)$. This fits with the previously found broader $\mathrm{T}$ cell host range of SI variants (19). In the natural course of HIV-1 infection, the emergence of SI variants has been shown to correlate with both accelerated $\mathrm{CD}^{+} \mathrm{T}$ cell decline and accelerated disease progression (20-23). The same has been found during treatment (24-28). Moreover, individuals harboring only NSI HIV-1 variants were shown to benefit more from treatment with zidovudine (ZDV) than individuals also harboring SI variants (26). Using a limiting dilution culture protocol, we demonstrated previously that this differential benefit of ZDV correlates well with a differential response to therapy of cellular SI and NSI HIV-1 load, which could not be explained by differences in the rate of resistance development between both variants (29).

1. Abbreviations used in this paper: CCR5, $\beta$ chemokine receptor-5; CXCR4, $\alpha$ chemokine receptor-4; ddI, didanosine; NSI, nonsyncytium-inducing; SI, syncytium-inducing; ZDV, zidovudine. 
In contrast with $\mathrm{ZDV}$, didanosine (ddI) monotherapy has been reported to result in the loss of SI variants $(30,31)$. In addition, despite its capacity to pass the blood-brain barrier (32), ddI does not have the pronounced and long lasting effect on reversing AIDS dementia in adults as observed for ZDV (33, 34), which suggests different targets for the two drugs. Indeed, in vitro, ZDV and ddI have been shown to work synergistically, and several large clinical trials, together representing HIV-1-infected individuals in different stages of HIV-1 infection with a broad range of $\mathrm{CD}^{+} \mathrm{T}$ cell numbers, have shown the increased clinical benefit of combined ZDV and ddI (3538). To further investigate this viral phenotype-dependent response to nucleoside analog treatment, we studied treatment responses in serum and in infectious cellular virus loads during ZDV or ddI monotherapy or ZDV/ddI combination therapy. For comparison, the clonal composition of virus populations during treatment with the protease inhibitor ritonavir was studied.

\section{Methods}

Study population. 10 antiretroviral treatment-naive asymptomatic HIV-1-infected individuals attending the Municipal Health Service as part of the Amsterdam Cohort Studies on HIV and AIDS in homosexual men, participated in a previously described ZDV dose-efficacy study $(24,29,39)$ that started in 1987 (dose $1000 \mathrm{mg}$ daily). 4 of these 10 individuals also received aciclovir prophylaxis as part of this study (ACH numbers $0105,0232,0316$, and 0346). Written informed consent was obtained from all participants in the Amsterdam Cohort Studies of HIV infection and AIDS. In the conduct of clinical research human experimentation guidelines of the authors' institutions were followed.

Seven HIV-1-infected individuals attending the Academic Medical Centre participated in a previously described international study on the effects of two doses of ddI (40) that started in 1990. These seven individuals were previously treated with ZDV $(26,39)$, but stopped therapy because of adverse events. After a washout period of at least 4 wk they started with ddI (dose 200-400 mg daily). Six of these seven individuals received cotrimoxazol, pentamidine, ketocoxazol, and/or aciclovir as prophylaxis. Two were diagnosed with AIDS on the basis of Pneumocystis carinii pneumonia before start of treatment (ACH numbers 8308 and 0053).

Four antiretroviral treatment-naive HIV-1-infected individuals attending the Academic Medical Centre were treated with a combination of ZDV and ddI within two previously described trials $(35,36)$ that started in 1991 and 1993 (dose $600 \mathrm{mg}$ ZDV daily and 200-400 $\mathrm{mg}$ ddI daily). One of these four individuals (d271) was diagnosed with AIDS based on Pneumocystis carinii pneumonia and received cotrimoxazol before the start of the study.

Four protease-inhibitor treatment-naive HIV-1-infected individuals participated in two trials on the efficacy of ritonavir (41) that started in 1994 and 1995 (dose 900-1200 mg daily). One of these four individuals (id235) had received ZDV and cotrimoxazol for $9 \mathrm{mo}$, but stopped taking ZDV 1 mo before starting ritonavir.

To be able to compare the treatment effects in our different study groups, subjects were selected from the latter three studies for the presence or absence at baseline of SI variants in bulk coculture, on the basis of baseline CD4 counts (between 50 and 300 cells $/ \mu \mathrm{l}$ ), and on the availability of cryopreserved patient PBMC samples at baseline and at appropriate time points after start of treatment $(1,3$, and 6 mo). We analyzed $\mathrm{CD}^{+}{ }^{+} \mathrm{T}$ cell numbers, serum HIV RNA load, and cellular infectious load at baseline between the four treatment groups, both for those individuals harboring only NSI variants and for those harboring both SI and NSI variants (Table I and II). Baseline $\mathrm{CD} 4^{+} \mathrm{T}$ cell numbers invariably were higher in individuals harboring only NSI variants. However, only the ZDV-treated individuals had higher baseline $\mathrm{CD} 4^{+} \mathrm{T}$ cell numbers. Neither the clonal composition at baseline nor the absolute infectious cellular load differed significantly between any of the study groups.

Virological assays. From all 25 individuals, cryopreserved PBMC and serum samples obtained from sequential time points, from 2 mo before up to $1 \mathrm{yr}$ after initiation of treatment, were analyzed.

Determination of the proportion of productively infected cells and isolation of biological virus clones was performed using a previously described limiting dilution culture system $(5,29,42)$. Briefly, patient PBMC (2,500-40,000 cells per well, 24-96 replicates per cell concentration) were cocultivated in 96 -well plates, with $10^{5} 3$-d phytohemagglutinin (PHA)-stimulated fresh PBMC from healthy blood donor volunteers. Every week for $5 \mathrm{wk}, 65 \mu \mathrm{l}$ of culture supernatants were collected for detection of p24 antigen by an in-house p24 capture ELISA. At the same time, half of the cells were transferred to new 96-well plates and $10^{5}$ fresh PHA-stimulated healthy donor PBMC were added to propagate the culture. SI capacity of the virus clones was determined by cocultivation of the remaining cells with MT-2 cells (20). The proportion (F) of infected cells was determined according to the formula for Poisson distribution: $\mathrm{F}=-\ln \left(\mathrm{F}_{0}\right)$, in which $\mathrm{F}_{0}$ is the fraction of negative cultures. Since $\mathrm{CD} 4^{+} \mathrm{T}$ cells have been shown to be the most important target for HIV-1 in the peripheral blood (43), virus load is expressed as the tissue culture infectious dose (TCID) per $10^{6} \mathrm{CD} 4^{+} \mathrm{T}$ cells.

Serum HIV-1 RNA levels were determined using reverse transcriptase (RT)-PCR (Amplicor HIV-1 monitor assay; Roche Molecular Systems, Branchburg, NJ) (44) in two subjects on combined ZDV/ ddI treatment and in the four subjects on ritonavir treatment or nu-

Table I. Median CD4 $4^{+}$Lymphocyte Numbers and Serum HIV RNA Levels at Baseline

\begin{tabular}{|c|c|c|c|c|c|c|}
\hline \multirow[b]{2}{*}{ Treatment } & \multirow[b]{2}{*}{$n$} & \multicolumn{2}{|c|}{ Individuals with only NSI } & \multirow[b]{2}{*}{$n$} & \multicolumn{2}{|c|}{ Individuals with both SI and NSI } \\
\hline & & $\mathrm{CD} 4^{+} \mathrm{T}$ cells* & RNA levels $^{\ddagger}$ & & $\mathrm{CD} 4^{+} \mathrm{T}$ cells* & RNA levels ${ }^{\ddagger}$ \\
\hline $\mathrm{ZDV}$ & 7 & $400(290-710)$ & $4.66(4.00-5.42)$ & 3 & $190(190-240)$ & $4.42(4.11-4.91)$ \\
\hline ddI & 2 & $220(200-240)$ & $5.78(5.70-5.86)$ & 5 & $110(60-130)$ & $5.20(4.80-5.75)$ \\
\hline $\mathrm{ZDV}+\mathrm{ddI}$ & 0 & NA & NA & 4 & $205(80-280)$ & $4.63(3.80-4.91)$ \\
\hline Ritonavir & 2 & $165(120-210)$ & $5.24(5.19-5.28)$ & 2 & $260(230-290)$ & $5.54(5.41-5.67)$ \\
\hline
\end{tabular}

* Expressed as cells per microliter; ${ }^{*}$ expressed as log copies per milliliter; numbers between parentheses indicate range; $\mathrm{NA}=$ not applicable (no individuals with only NSI variants on ZDV/ddI combination therapy were studied). Mann-Whitney rank sum test for differences between treatment groups: $\mathrm{CD}^{+}{ }^{+} \mathrm{T}$ lymphocyte numbers in NSI only carriers, ZDV versus ddI, $P=0.040$, ZDV versus ritonavir, $P=0.040$; $\mathrm{CD}^{+} \mathrm{T}$ lymphocyte numbers in NSI plus SI carriers: ZDV versus ddI, $P=0.025$; Serum HIV RNA levels in NSI carriers, ZDV versus ddI, $P=0.040$. No other comparisons in baseline $\mathrm{CD}^{+} \mathrm{T}$ lymphocyte numbers or serum HIV RNA levels between the groups reached statistical significance. 
a total infectious cellular load

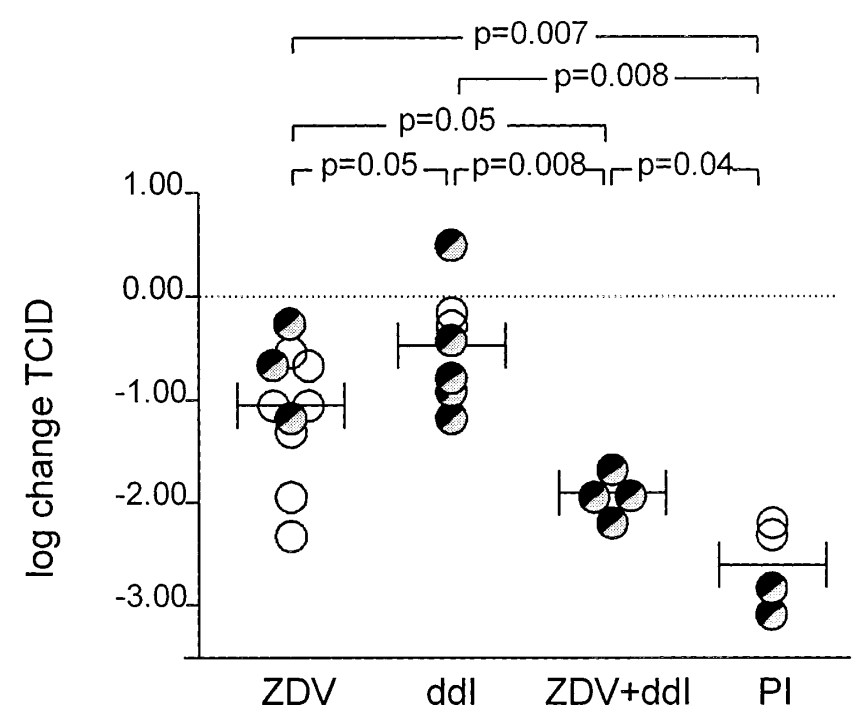

b NSI infectious cellular load

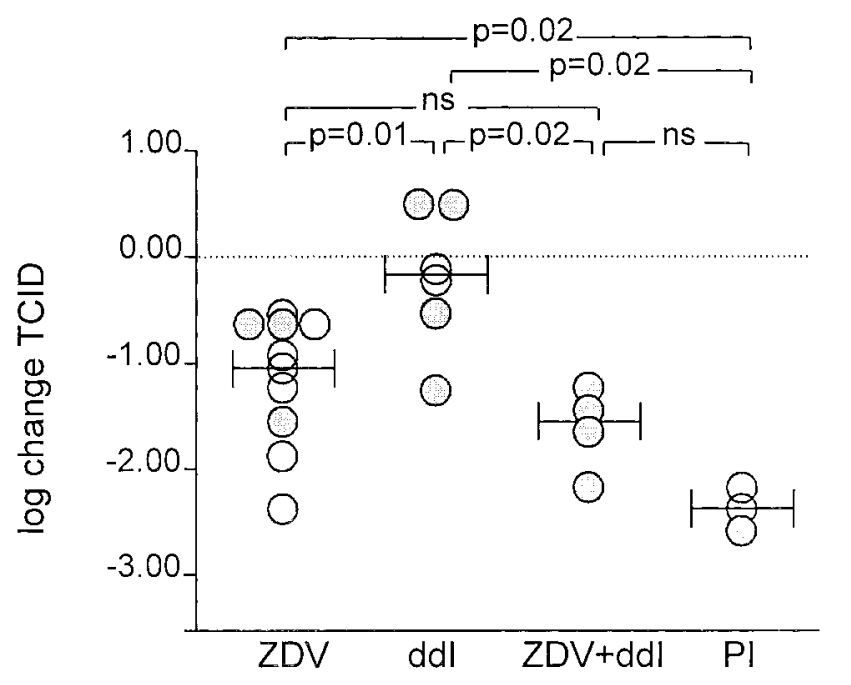

cleic acid based amplification assay (NASBA HIV-1 RNA QT; Organon Teknika, Boxtel, The Netherlands) (45) in the other subjects. Per individual all samples were assayed in batch.

Statistical analysis. Number Crunching Statistical Systems (NCSS,
Figure 1. Maximal changes in infectious cellular load observed within 6 mo after start of antiviral therapy. Each dot represents the maximal response for one individual. (a) Changes in total infectious cellular load. Open circles represent individuals carrying only NSI variants, black/ gray circles represent individuals carrying both SI and NSI variants. (b) Changes in NSI infectious cellular load. Open circles represent NSI load in individuals carrying only NSI variants, gray circles represent NSI load in individuals carrying both SI and NSI variants. (c) Changes in SI infectious cellular load. Black circles represent SI load in individuals carrying both SI and NSI variants. $P$ values from the Mann-Whitney rank sum test for differences between the four treatment groups are shown. $P I$, protease inhibitor ritonavir; $n s$, not significant.

\section{c SI infectious cellular load}

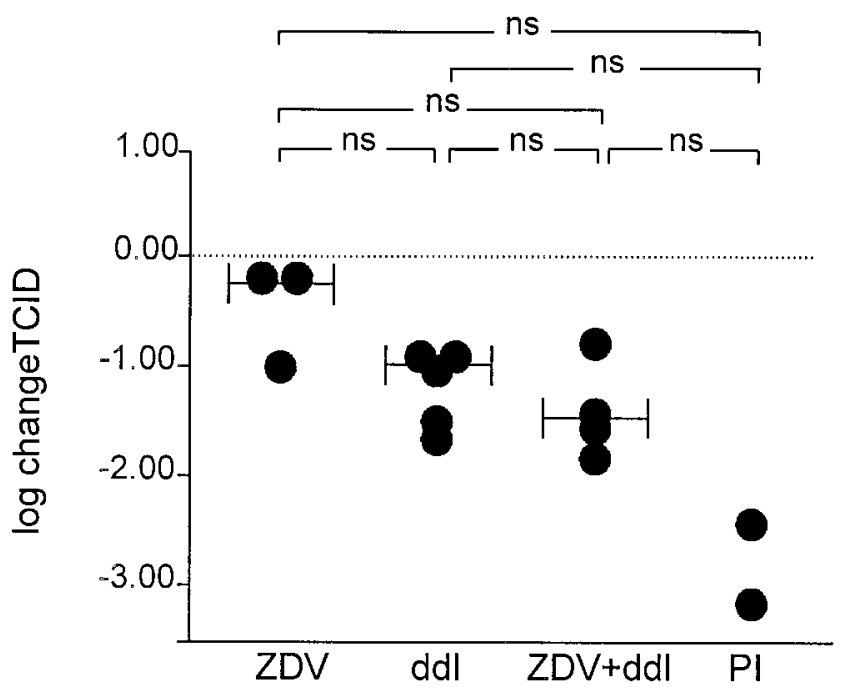

version 6.0, Klaysville, UT) was used for statistical analyses. Viral load measurements were log-base 10 transformed before statistical analysis. Mann-Whitney rank sum test was used to calculate differences in baseline levels and treatment responses in CD4 cell counts, serum

Table II. Median NSI and SI Infectious Cellular Load and Percentages of SI Variants at Baseline

\begin{tabular}{|c|c|c|c|c|c|c|}
\hline \multirow[b]{2}{*}{ Treatment } & \multicolumn{2}{|c|}{ Individuals with only NSI } & \multicolumn{4}{|c|}{ Individuals with both SI and NSI } \\
\hline & $n$ & NSI load* & $n$ & NSI load* & SI load* & Percentage SI \\
\hline ZDV & 7 & $1.78(1.28-2.35)$ & 3 & $2.20(1.43-2.39)$ & $1.58(1.11-2.47)$ & $52 \%(32-53)$ \\
\hline ddI & 2 & $1.96(1.68-2.23)$ & 5 & $1.93(0.00-2.62)$ & $1.64(0.90-2.55)$ & $49 \%(33-100)$ \\
\hline $\mathrm{ZDV}+\mathrm{ddI}$ & 0 & NA & 4 & $1.55(1.26-2.19)$ & $1.47(0.86-1.81)$ & $49 \%(28-59)$ \\
\hline Ritonavir & 2 & $2.27(2.16-2.37)$ & 2 & $1.30(0.00-2.59)$ & $2.82(2.50-3.14)$ & $75 \%(49-100)$ \\
\hline
\end{tabular}

* Expressed as log TCID per $10^{6} \mathrm{CD} 4$; numbers between parentheses indicate range; NA $=$ not applicable (no individuals with only NSI variants on ZDV/ddI combination therapy were studied). Baseline SI and NSI infectious cellular load did not differ significantly between the treatment groups. 

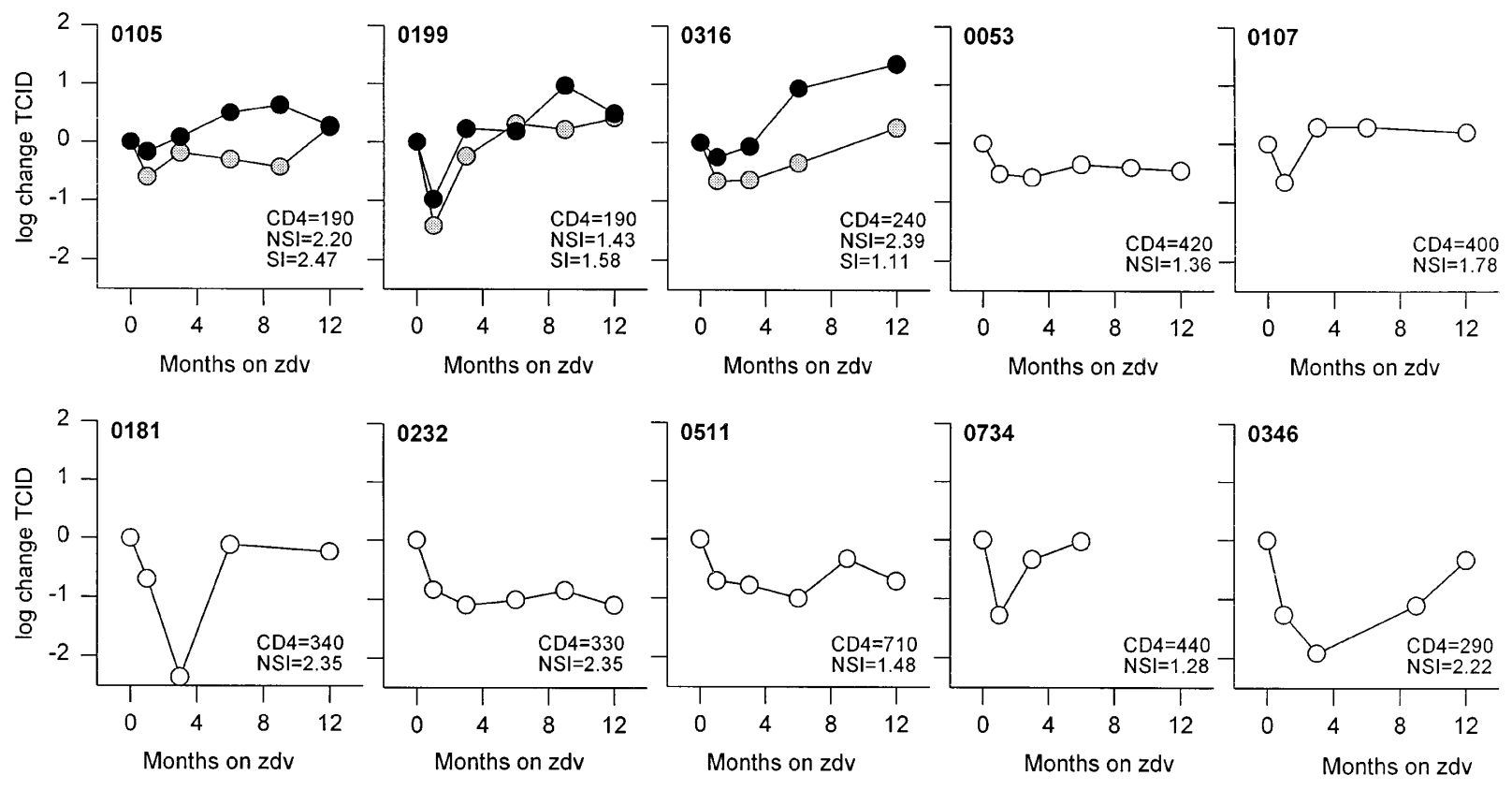

b ddl monotherapy
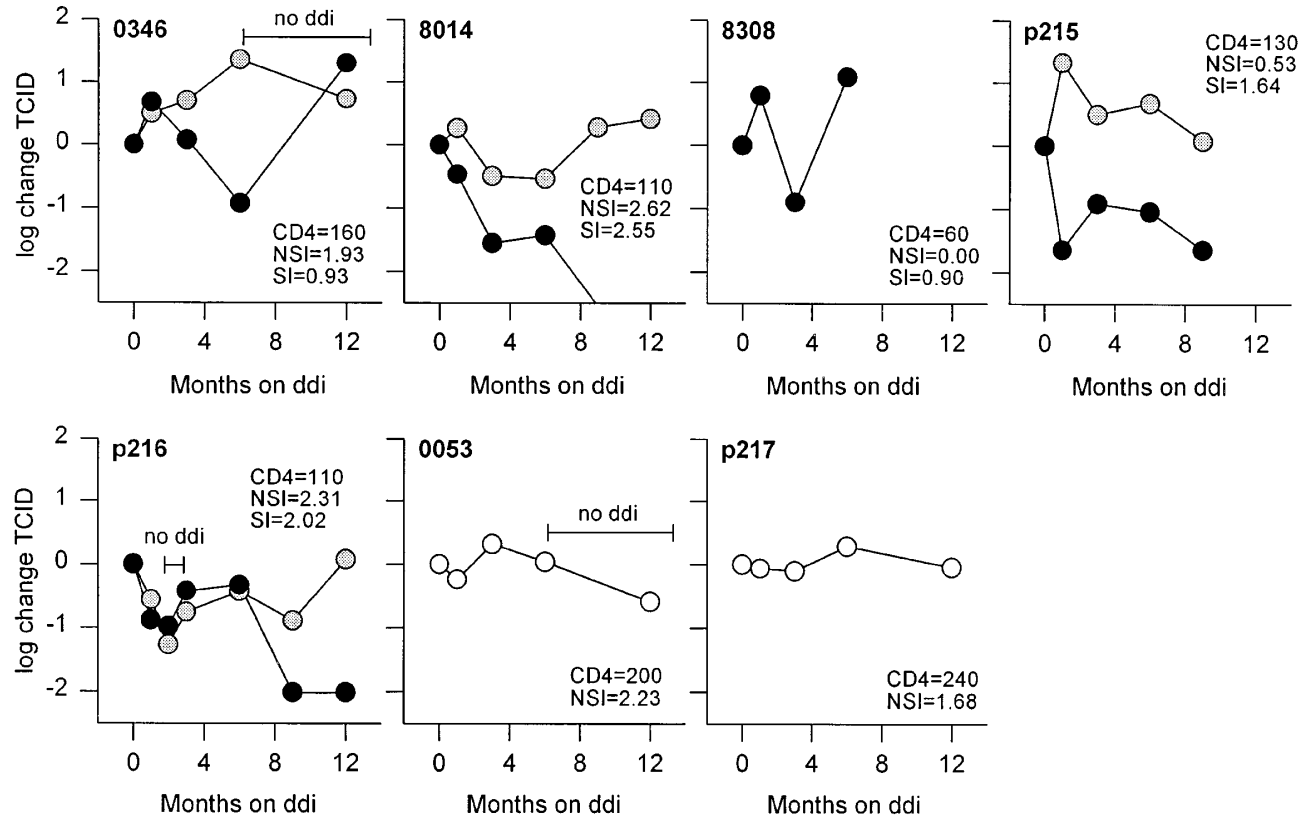

c ZDV+ddl combination therapy

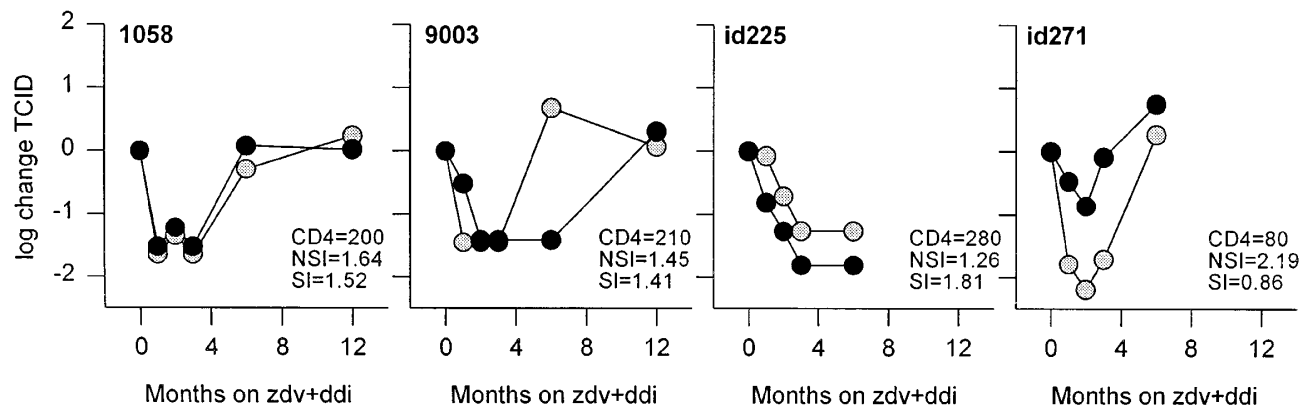


Ritonavir monotherapy

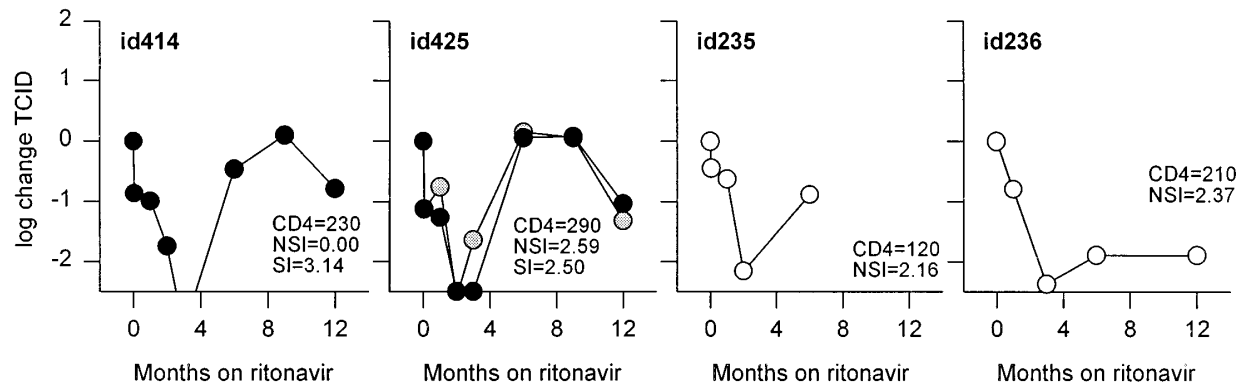

Figure 3. Changes in SI and NSI HIV-1 populations relative to baseline levels in relation to time after start of protease inhibitor treatment. $\mathrm{CD}^{+}{ }^{+} \mathrm{T}$ lymphocyte numbers (expressed as cells per microliter) and NSI and SI infectious cellular load (expressed as log TCID per $10^{6} \mathrm{CD} 4$ cells) at baseline are given for each individual. Open circles represent the NSI load in individuals carrying only NSI variants, gray and black circles represent NSI and SI load, respectively, in individuals harboring both variants.
RNA load and SI and NSI infectious cellular load between the four different treatment groups.

\section{Results}

Changes in $\mathrm{CD}^{+} T$ cell numbers, serum HIV-1 RNA load, and infectious cellular load during nucleoside analog treatment. The ZDV-treated group showed the largest response in $\mathrm{CD}^{+} \mathrm{T}$ cell numbers (median increase 250 cells/ $\mu \mathrm{l}$, range -70-470) compared with the group on ddI monotherapy (median increase 30 cells/ $\mu$ l, range $-60-300)$, and ZDV/ddI combination therapy (median increase $130 \mathrm{cells} / \mu \mathrm{l}$, range $20-200$ ) (46). The latter group showed a strong decline in serum RNA load (median $-1.72 \log$ [range -2.36 to -1.42 ]), while ZDV or ddI monotherapy caused moderate decreases (ZDV: median $-0.63 \log$ [range $-1.76-0.47])$ and ddI: median $-0.57 \log$ (range -1.03 to -0.27 ).

For the majority of treated individuals, the maximal response to treatment in infectious cellular load was observed before the 3 mo time point. Fig. $1 a$ depicts the maximal declines observed within 6 mo after initiation of treatment. During treatment with the combination of ZDV and ddI, a stronger response was observed (median $-1.91 \log$ [range -2.21 to -1.73]) than either in the group on ZDV monotherapy (median $-1.05 \log$ [range -2.35 to -0.28$]$ ) or in the group on ddI monotherapy (median -0.74 log [range $-1.15-0.52$ ], Mann Whitney rank sum test, $P=0.05$ and 0.008 , respectively).

Changes in infectious cellular SI and NSI virus load during nucleoside analog treatment. As we observed previously that the coexisting SI and NSI populations responded differentially to ZDV treatment, we next analyzed changes in these virus populations during treatment with ddI alone or in combination with ZDV. Baseline levels of SI and/or NSI infectious cellular load and the percentages of SI variants present at baseline were not significantly different between any of the nucleoside analog treatment groups when comparing the individuals harboring only NSI variants or those harboring both SI and NSI variants (Table II). Changes in the infectious cellular SI and
NSI load for each subject in the three different nucleoside ana$\log$ treatment groups are shown in Fig. 2. Different responses in infectious cellular NSI and SI load were observed depending on the nucleoside analog treatment regimen. As reported previously (29), during ZDV treatment, a preferential inhibition of NSI variants was observed while the SI load was less affected. In individuals receiving ddI monotherapy, however, the opposite phenomenon was observed: SI virus load showed a substantial decrease, while NSI virus load remained mostly unchanged. In individuals on ZDV/ddI combination therapy, SI and NSI virus load were equally affected and their responses to treatment showed similar kinetics.

Within the different treatment groups, responses in NSI load were comparable between individuals, i.e., NSI load declined in all individuals under ZDV treatment and under ZDV/ ddI combination treatment, and was not affected during ddI treatment. Moreover, the changes in SI load followed the same patterns for the different individuals within a treatment group, i.e., SI load declined during ddI and ZDV/ddI combination treatment, and was less affected during ZDV treatment. This prompted us to combine the data on cellular SI and NSI HIV-1 load from all individuals for each different treatment group to perform statistical analysis. Maximum responses in SI and NSI infectious cellular load observed within the first 6 mo after initiation of treatment are shown in Fig. 1, $b$ and $c$. ZDV treatment resulted in a preferential inhibition of NSI virus load (NSI: median $-0.94 \log$ [range -2.35 to -0.58 ], SI: median $-0.25 \log$ [range -0.98 to -0.17 ], $P=0.06$ ), while ddI preferentially affected SI virus load (NSI: median $-0.15 \log$ [range $-1.27-0.50$ ], SI: median $-0.98 \log$ [range $-1.55-0.08$ ], $P=$ $0.03)$. Because of the low number of SI carriers in this ZDV monotherapy group, the differences in response did not reach statistical significance (29). In response to ZDV/ddI combination treatment, the changes in NSI and SI infectious cellular load closely resembled a sum of the changes observed in NSI load in individuals receiving only ZDV and in SI load in individuals receiving only ddI (NSI: median -1.55 log [range -2.19 to -1.45 ], SI: median $-1.47 \log$ [range -1.81 to -0.86 ,

Figure 2. Changes in SI and NSI HIV-1 populations relative to baseline levels in relation to time after start of nucleoside analog treatment. $(a)$ Individuals on ZDV monotherapy, (b) individuals on ddI monotherapy, and (c) individuals on ZDV/ddI combination therapy. CD4 ${ }^{+} \mathrm{T}$ lymphocyte numbers (expressed as cells per microliter) and NSI and SI infectious cellular load (expressed as $\log$ TCID per $10^{6}$ CD4 cells) at baseline are given for each individual. Open circles represent the NSI load in individuals carrying only NSI variants, gray and black circles represent NSI and SI load, respectively, in individuals harboring both variants. 
$P=0.56)$. For both phenotypic groups the combination therapy seemed to have additional inhibitory effect.

Changes in infectious cellular SI and NSI virus load during protease inhibitor therapy. Nucleoside analogs are prodrugs that require intracellular phosphorylation for their activity. We hypothesized that differences in prodrug activation in combination with the differential T cell tropism of SI and NSI HIV-1, may underlie the observed differences in response to nucleoside analog therapy. Therefore, we wanted to analyze changes in SI and NSI virus populations during treatment with a compound that does not need to be metabolized, such as HIV-1 protease inhibitors.

We analyzed treatment responses in four individuals, who were treated with the protease inhibitor ritonavir. Baseline characteristics of these subjects are shown in Tables I and II. An $\sim 2$-log drop in virus load was observed in all individuals (serum RNA load: median $-1.86 \log$ [range -2.59 to -1.51 ]; infectious cellular load: median $-2.61 \log$ [range -3.14 to -2.16]), which in magnitude was similar to that observed in individuals on ZDV/ddI combination treatment. As shown in Figs. 1 and 3, SI and NSI variants were affected equally by ritonavir treatment (NSI: median $-2.37 \log$ [range -2.59 to $-2.16]$, SI: median $-2.82 \log$ (range -3.14 to -2.50$)(P=$ $0.25)$.

\section{Discussion}

Previously, we have reported a preferential inhibition of NSI variants by ZDV. The absence of an effect on SI variants could not be explained fully by the emergence of resistance conferring mutations in the reverse transcriptase gene (29). Others have since shown that ddI treatment results in a loss of SI variants in bulk cocultures $(30,31)$. Moreover, results of several large clinical trials have now shown the increased clinical benefit of the combined treatment with ZDV and ddI (35-38). To further understand and elucidate this phenomenon we studied the clonal composition of HIV-1 populations in several additional subjects treated with either ddI alone or in combination with ZDV. In contrast with ZDV, ddI monotherapy resulted in a selective loss of SI variants. However, neither total cellular virus load, $\mathrm{CD}^{+} \mathrm{T}$ cell numbers, nor serum RNA load were much affected, which combines well with the observations on the minor clinical benefit of ddI monotherapy in heavily-pretreated, late stage HIV-1-infected individuals such as the subjects in this and other studies $(40,47)$. Combination therapy of ddI and ZDV resulted in a 1.5-2.5 log decline in both infectious cellular (both in NSI and SI load) and in serum HIV-1 load, again correlating with the in vivo clinical benefit observed in several large clinical trials (35-38).

Because of the retrospective nature of this study, the different treatment groups varied with respect to year of initiation of treatment, OI prophylaxis, and disease stage. The ZDV monotherapy group especially differed at baseline from the other two nucleoside analog treatment groups with respect to baseline $\mathrm{CD}^{+}{ }^{+} \mathrm{T}$ cell numbers and serum HIV-1 RNA load. In addition, all individuals receiving ddI monotherapy were ZDV experienced (median duration 13 mo [range 6-40 mo] and resistance mutations for ZDV might have influenced the ddI response [48]). Although, because of these differences, a comparison of clinical effect of the different treatment regimens is not allowed, the consistent HIV-1 phenotype-dependent responses to treatment with $\mathrm{ZDV}$ and/or ddI suggest that the differences at baseline do not influence the virus phenotype dependent responses. Moreover, the fact that the percentage of SI variants present at baseline was comparable between all three nucleoside analog treatment groups further strengthens the notion that ZDV pretreatment of the ddI group did no longer influence the virus population by the time ddI treatment was initiated. Finally, when analyzing a group of individuals who started on ZDV monotherapy in 1993 similar results were obtained to the results obtained with the ZDV monotherapy group that started in 1987 (29).

In our previous study, we showed that the differences in the infectious cellular load responses of SI and NSI HIV-1 were not due to differences in the rate by which ZDV resistance mutations were acquired (29). Mutations conferring ddI resistance are generally not observed before 6 mo after initiation of monotherapy and phenotypic ddI resistance has rarely been demonstrated $(35,49,50)$. Moreover, no differences in ddI resistance development were found between individuals harboring only NSI variants and those also harboring SI variants despite differences in $\mathrm{CD}^{+}{ }^{+} \mathrm{T}$ cell response (27). The differential declines in infectious cellular load already $12 \mathrm{wk}$ after initiation of treatment may therefore be considered independent of resistance mutations. The rebound in virus load, however, might well be due to the emergence of drug resistant viruses.

The observed HIV-1 phenotype-specific activity of ZDV and ddI may be explained by the activation mechanism of nucleoside analogs (ddN). Like the activation of nucleosides, activation of ddN requires phosphorylation which is dependent on cellular kinases whose expression and activity are cell type specific (51-53). ZDV and stavudine (d4T) are phosphorylated by kinases that are only active in activated cells. In contrast, the cellular kinases responsible for phosphorylation/activation of ddI, zalcitabine (ddC), and lamivudine (3TC) are potent in quiescent cells. From this latter group the cytidine analogs (ddC, 3TC), but not the purine analog ddI, are even more phosphorylated in activated cells (51). The enhanced phosphorylation of ZDV in activated cells was shown to even overcome the increase in virus production induced by the activation, whereas ddI was not able to do so (53). These results suggest that the anti-HIV-1 activity of ZDV is superior in activated cells, whereas ddI is more effective in resting cells $(52,53)$.

Recently, the coreceptors for NSI and SI HIV-1 variants have been identified (9-14). While CXCR4 is widely expressed also on resting $\mathrm{T}$ lymphocytes, the expression of CCR5 is low on quiescent $\mathrm{T}$ cells and only significantly upregulated after stimulation $(17,18,54)$. Moreover, a largely reciprocal expression of CXCR4 and CCR5 among peripheral blood T cells has been reported (55). CXCR4 is expressed predominantly on unactivated naive $\mathrm{CD} 26^{\text {low }} \mathrm{CD} 45 \mathrm{RA}^{+} \mathrm{CD} 45 \mathrm{R} 0^{-} \mathrm{T}$ lymphocyte subset, while CCR5 is found on CD26 $6^{\text {high }}$ CD45RA ${ }^{\text {low }}$ $\mathrm{CD} 45 \mathrm{R} 0^{+} \mathrm{T}$ lymphocytes thought to represent activated $/ \mathrm{mem}$ ory cells. Thus, as NSI and SI HIV-1 variants may have different cellular tropisms for activated/memory and resting/naive $\mathrm{T}$ cells, respectively, specific coreceptor expression coinciding with the presence of cellular kinases specific for phosphorylation of certain ddN, may contribute to the virus phenotypedependent effect of different ddN. We propose the following hypothetical model to explain the virus phenotype dependent efficacy of nucleoside analogs. In this model, ZDV is preferentially active in activated CCR5 expressing cells that can be infected by NSI HIV-1 variants, while ddI preferentially acts in quiescent CXCR4 expressing cells that support SI HIV-1 in- 
fection. The combination of ZDV and ddI then covers both cell types and thereby inhibits both phenotypic variants. Protease inhibitors, which do not require intracellular phosphorylation, are as active in quiescent as in activated cells (53). In agreement with our model, we observed an equal inhibition of NSI and SI HIV-1 populations in individuals receiving the protease inhibitor ritonavir. Primary SI variants are capable to use both CCR5 and CXCR4 for entry $(15,16)$. Indeed, ZDV, presumed to work preferentially in CCR5 expressing cells, also partially inhibits SI virus load. On the other hand, primary SI variants do not seem to escape ddI, presumed to work preferentially in CXCR4 expressing cells, by replicating in CCR5 expressing cells. Apparently, in these individuals, the SI variants are not able to compete with the NSI variants for these targets. This would be in agreement with the findings that NSI variants always remain present and significantly contribute to viral load even after the emergence of SI variants (42).

Further evidence to support our model can be deduced from the effective treatment with ddI, thought to be active in naive cells, of HIV-1-infected children in whom naive cells are abundant (47). The virus populations present in naive and memory cells in HIV-1-infected individuals and the tropism of NSI and SI HIV-1 variants for these cells are currently under study.

In conclusion, the potential for effective combination antiviral therapy might be enhanced if drugs from each of the two categories, the cell activation-dependent ddNs and the cell activation-independent ddNs, are included. It should be noted, however, that toxicity profiles, bioavailability in all tissue compartments, and resistance profiles also have to be considered as critical factors in designing effective combination chemotherapy.

\section{Acknowledgments}

These studies were performed as part of the Amsterdam Cohort Studies of AIDS, a collaboration between the Municipal Health Service, the Academic Medical Centre, and the Central Laboratory of the Netherlands Red Cross Blood Transfusion Service, Amsterdam, The Netherlands. Proleukin (rIL-2) was kindly provided by Dr. R. Rombouts, Chiron Benelux B.V., Amsterdam, The Netherlands. The antiviral trials were supported by GlaxoWellcome, Bristol-Myers Squibb, Roche, and Abbott Laboratories. The authors are greatly indebted to all individuals participating in these studies, to Neeltje Kootstra, Jeanette van der Hulst, and Marijke Roos and colleagues for excellent technical assistance, to Gerrit-Jan Weverling for providing patient data, to Rob Schuurman for stimulating discussions, and to Maarten Koot and Michèl Klein for critically reading the manuscript.

This work was supported by grants from the Netherlands Ministry of Public Health, the Netherlands Foundation for Preventive Medicine, and the National AIDS Therapy Evaluation Centre.

\section{References}

1. Tersmette, M., R.E.Y. De Goede, B.J.M. Al, I.N. Winkel, R.A. Gruters, H.T.M. Cuypers, H.G. Huisman, and F. Miedema. 1988. Differential syncytium-inducing capacity of human immunodeficiency virus isolates: frequent detection of syncytium-inducing isolates in patients with acquired immunodeficiency syndrome (AIDS) and AIDS-related complex. J. Virol. 62:2026-2032.

2. Cheng-Mayer, C., D. Seto, M. Tateno, and J.A. Levy. 1988. Biologic features of HIV-1 that correlate with virulence in the host. Science (Wash. DC). $240: 80-82$.

3. Asjo, B., J. Albert, A. Karlsson, L. Morfeldt-Månson, G. Biberfeld, K. Lidman, and E.M. Fenyö. 1986. Replicative capacity of human immunodeficiency virus from patients with varying severity of HIV infection. Lancet. II: $660-662$.
4. Tersmette, M., R.A. Gruters, F. De Wolf, R.E.Y. De Goede, J.M.A Lange, P.Th.A. Schellekens, J. Goudsmit, J.G. Huisman, and F. Miedema. 1989. Evidence for a role of virulent human immunodeficiency virus (HIV) variants in the pathogenesis of acquired immunodeficiency syndrome: studies on sequential HIV isolates. J. Virol. 63:2118-2125.

5. Schuitemaker, H., M. Koot, N.A. Kootstra, M.W. Dercksen, R.E.Y. De Goede, R.P. Van Steenwijk, J.M.A. Lange, J.K.M. Eeftink Schattenkerk, F. Miedema, and M. Tersmette. 1992. Biological phenotype of human immunodeficiency virus type 1 clones at different stages of infection: progression of disease is associated with a shift from monocytotropic to T-cell-tropic virus populations. J. Virol. 66:1354-1360.

6. Connor, R.I., H. Mohri, Y. Cao, and D.D. Ho. 1993. Increased viral burden and cytopathicity correlate temporally with $\mathrm{CD}^{+}{ }^{+} \mathrm{T}$-lymphocyte decline and clinical progression in human immunodeficiency virus type 1 infected individuals. J. Virol. 67:1772-1777.

7. Zhu, T., H. Mo, N. Wang, D.S. Nam, Y. Cao, R.A. Koup, and D.D. Ho. 1993. Genotypic and phenotypic characterization of HIV-1 in patients with primary infection. Science (Wash. DC). 261:1179-1181.

8. Van 't Wout, A.B., N.A. Kootstra, G.A. Mulder-Kampinga, N. Albrechtvan Lent, H.J. Scherpbier, J. Veenstra, K. Boer, R.A. Coutinho, F. Miedema, and H. Schuitemaker. 1994. Macrophage-tropic variants initiate human immunodeficiency virus type 1 infection after sexual, parenteral and vertical transmission. J. Clin. Invest. 94:2060-2067.

9. Deng, H.K., R. Liu, W. Ellmeier, S. Choe, D. Unutmaz, M. Burkhart, P. Di Marzio, S. Marmon, R.E. Suttons, C.M. Hill, et al. 1996. Identification of the major co-receptor for primary isolates of HIV-1. Nature (Lond.). 381:661-666.

10. Dragic, T., V. Litwin, G.P. Allaway, S.R. Martin, Y. Huang, K.A. Nagashima, C. Cayanan, P.J. Maddon, R.A. Koup, J.P. Moore, and W.A. Paxton 1996. HIV-1 entry into CD $4^{+}$cells is mediated by the chemokine receptor CCCKR-5. Nature (Lond.). 381:667-673.

11. Alkhatib, G., C. Combadiere, C.C. Broder, Y. Feng, P.E. Kennedy, P.M. Murphy, and E.A. Berger. 1996. CC CKR5: A RANTES, MIP-1 $\alpha$, MIP$1 \beta$ receptor as a fusion cofactor for macrophage-tropic HIV-1. Science (Wash. DC). 272:1955-1958.

12. Choe, H., M. Farzan, Y. Sun, N. Sullivan, B. Rollins, P.D. Ponath, L. Wu, C.R. Mackay, G. LaRosa, W. Newman, et al. 1996. The $\beta$-chemokine receptors CCR3 and CCR5 facilitate infection by primary HIV-1 isolates. Cell. 85:1135-1148

13. Doranz, B.J., J. Rucker, Y. Yi, R.J. Smyth, M. Samson, S.C. Peiper, M. Parmentier, R.G. Collman, and R.W. Doms. 1996. A dual-tropic primary HIV-1 isolate that uses fusin and the $\beta$-chemokine receptors CKR-5, CKR-3 and CKR-2b as fusion cofactors. Cell. 85:1149-1158.

14. Feng, Y., C.C. Broder, P.E. Kennedy, and E.A. Berger. 1996. HIV-1 entry cofactor: functional cDNA cloning of a seven-transmembrane, $G$ proteincoupled receptor. Science (Wash. DC). 272:872-877.

15. Zhang, L., Y. Huang, T. He, Y. Cao, and D.D. Ho. 1996. HIV-1 subtype and second-receptor use. Nature (Lond.). 383:768.

16. Simmons, G., D. Wilkinson, J.D. Reeves, M.T. Dittmar, S. Beddows, J. Weber, G. Carnegie, U. Desselberger, P.W. Gray, R.A. Weiss, and P.R. Clapham. 1996. Primary, syncytium-inducing human immunodeficiency virus type 1 isolates are dual-tropic and most can use either LESTR or CCR5 as coreceptors for virus entry. J. Virol. 70:8355-8360.

17. Oberlin, E., A. Amara, F. Bachelerie, C. Bessia, J.-L. Virelizier, F. Arenzana-Seisdedos, O. Schwartz, J.-M. Heard, I. Clark-Lewis, D.F. Legler, M. Loetscher, M. Baggiolini, and B. Moser. 1996. The CXC chemokine SDF-1 is the ligand for LESTR/fusin and prevents infection by T-cell-line adapted HIV-1. Nature (Lond.). 382:833-835.

18. Bleul, C.C., M. Farzan, H. Choe, C. Parolin, I. Clark-Lewis, J. Sodroski, and T.A. Springer. 1996. The lymphocyte chemoattractant SDF-1 is a ligand for LESTR/fusin and blocks HIV-1 entry. Nature (Lond.). 382:829-832.

19. Fouchier, R.A.M., L. Meyaard, M. Brouwer, E. Hovenkamp, and H. Schuitemaker. 1996. Broader tropism and higher cytopathicity for $\mathrm{CD}^{+} \mathrm{T}$ cells of a syncytium-inducing compared to a non-syncytium inducing HIV-1 isolate as a mechanism for accelerated $\mathrm{CD}^{+} \mathrm{T}$ cell decline in vivo. Virology. 219:87-95.

20. Koot, M., A.H.V. Vos, R.P.M. Keet, R.E.Y. De Goede, W. Dercksen, F.G. Terpstra, R.A. Coutinho, F. Miedema, and M. Tersmette. 1992. HIV-1 biological phenotype in long term infected individuals, evaluated with an MT-2 cocultivation assay. AIDS. (Lond.). 6:49-54.

21. Koot, M., I.P.M. Keet, A.H.V. Vos, R.E.Y. De Goede, M.Th.L. Roos, R.A. Coutinho, F. Miedema, P.Th.A. Schellekens, and M. Tersmette. 1993. Prognostic value of human immunodeficiency virus type 1 biological phenotype for rate of $\mathrm{CD}^{+}$cell depletion and progression to AIDS. Ann. Intern. Med. 118:681-688.

22. Richman, D.D., and S.A. Bozzette. 1994. The impact of the syncytiuminducing phenotype of human immunodeficiency virus on disease progression. J. Infect. Dis. 169:968-974.

23. Karlsson, A., K. Parsmyr, E. Sandstrom, E.M. Fenyö, and J. Albert. 1994. MT-2 cell tropism as prognostic marker for disease progression in Human Immunodeficiency Virus type 1 infection. J. Clin. Microbiol. 32:364-370.

24. Boucher, C.A.B., J.M.A. Lange, F. Miedema, G.J. Weverling, M. Koot, J.W. Mulder, J. Goudsmit, P. Kellam, B.A. Larder, and M. Tersmette. 1992. HIV-1 biological phenotype and development of zidovudine resistance in rela- 
tion to disease progression in asymptomatic individuals during treatment. AIDS (Lond.). 6:1259-1264.

25. St. Clair, M.H., P.M. Hartigan, J.C. Andrews, C.L. Vavro, M.S. Simberkoff, J.D. Hamilton, and VA Cooperative Study Group. 1993. Zidovudine resistance, syncytium-inducing phenotype, and HIV disease in a case-control study. J. Acquired Immune Defic. Syndr. 6:891-897.

26. Koot, M., P.Th.A. Schellekens, J.W. Mulder, J.M.A. Lange, M.Th.L. Roos, R.A. Coutinho, M. Tersmette, and F. Miedema. 1993. Viral phenotype and T-cell reactivity in human immunodeficiency virus type 1-infected asymptomatic men treated with zidovudine. J. Infect. Dis. 168:733-736.

27. Karlsson, A., K. Parsmyr, K. Aperia, E. Sandstrom, E.M. Fenyö, and J. Albert. 1994. MT-2 cell tropism of human immunodeficiency virus type 1 isolates as a marker for response to treatment and development of drug resistance. J. Infect. Dis. 170:1367-1375.

28. Katzenstein, D.A. S.M. Hammer, M.D. Hughes, H. Gundacker, J.B. Jackson, S. Fiscus, S. Rasheed, T. Elbeik, R. Reichman, A.J. Japour, T.C. Merigan, M.S. Hirsch, and AIDS Clinical Trials Group 175 Virology Study Team. 1996. The relation of virologic and immunologic markers to clinical outcomes after nucleoside therapy in HIV-infected adults with 200 to 500 CD4 cells per cubic millimeter. N. Engl. J. Med. 335:1091-1098.

29. Van 't Wout, A.B., M.D. De Jong, N.A. Kootstra, J. Veenstra, J.M.A. Lange, C.A.B. Boucher, and H. Schuitemaker. 1996. Changes in cellular virus load and zidovudine resistance of syncytium-inducing and non-syncytiuminducing human immunodeficiency virus populations under zidovudine pressure: a clonal analysis. J. Infect. Dis. 174:845-849.

30. Delforge, M.-L., C. Liesnard, L. Debaisieux, M. Tchetcheroff, C.-M. Farber, and J.-P. Van Vooren. 1995. In vivo inhibition of syncytium inducing variants of HIV in patients treated with didanosine. AIDS (Lond.). 9:89-101.

31. Zheng, N.N., P.W. McQueen, L. Hurren, L.A. Evans, M.G. Law, S. Forde, S. Barker, and D.A. Cooper. 1996. Changes in biologic phenotype of human immunodeficiency virus during treatment of patients with didanosine. $J$. Infect. Dis. 173:1092-1096.

32. Burger, D.M., C.L. Kraayeveld, P.L. Meenhorst, J.W. Mulder, R.M.W. Hoetelmans, C.H.W. Koks, and J.H. Beijnen. 1995. Study on didanosine concentrations in cerebrospinal fluid. Pharm. World Sci. 17:218-221.

33. Portegies, P., J. de Gans, J.M.A. Lange, M.M.A. Derix, H. Speelman, M. Bakker, S.A. Danner, and J. Goudsmit. 1989. Declining incidence of AIDS dementia complex after introduction of zidovudine treatment. Br. Med. J. 299: 819-821.

34. Portegies, P., R.H. Entingh, M.D. De Jong, S.A. Danner, P. Reiss, J. Goudsmit, and J.M.A. Lange. 1994. AIDS dementia complex and didanosine. Lancet (N. Am. Ed.). 344:759.

35. Schooley, R.T., C. Ramirez-Ronda, J.M.A. Lange, D.A. Cooper, J. Lavelle, L. Lefkovits, M. Moore, B.A. Larder, M.H. St. Clair, J.W. Mulder, et al. 1996. Virologic and immunologic benefits of initial therapy with zidovudine and zalcitabine or didanosine compared with zidovudine monotherapy. J. Infect. Dis. 173:1354-1366.

36. Delta Coordinating Committee. 1996. Delta: a randomised double-blind controlled trial comparing combinations of zidovudine plus didanosine or zalcitabine with zidovudine alone in HIV-infected individuals. Lancet (N. Am. Ed.). 348:283-291.

37. Hammer, S.M., D.A. Katzenstein, M.D. Hughes, H. Gundacker, R.T. Schooley, R.H. Haubrich, W.K. Henry, M.M. Lederman, J.P. Phair, M. Niu, M.S. Hirsch, T.C. Merigan, and for the AIDS Clinical Trials Group Study 175 Study Team. 1996. A trial comparing nucleoside monotherapy with combination therapy in HIV-infected adults with CD4 cell counts from 200 to 500 per cubic millimeter. N. Engl. J. Med. 335:1081-1090.

38. Saravolatz, L.D., D.L. Winslow, G. Collins, J.S. Hodges, C. Pettinelli, D.S. Stein, N. Markowitz, R. Reves, M.O. Loveless, L. Crane, M. Thompson, D. Abrams, and Investigators for the Terry Beirn Community Programs for Clinical Research on AIDS. 1996. Zidovudine alone or in combination with didanosine or zalcitabine in HIV-infected patients with the acquired immunodeficiency syndrome or fewer than $200 \mathrm{CD} 4$ cells per cubic millimeter. N. Engl. J. Med. 335:1099-1106.

39. Mulder, J.W., F. De Wolf, J. Goudsmit, P.A. Cload, R.A. Coutinho, A.P. Fiddian, P.Th.A. Schellekens, J. Van der Noordaa, and J.M.A. Lange. 1990. Long-term zidovudine treatment of asymptomatic HIV-1-infected sub- jects. Antivir. Res. 13:127-138

40. Alpha International Coordinating Committee. 1996. The alpha trial: European/Australian randomized double-blind trial of two doses of didanosine in zidovudine-intolerant patients with symptomatic HIV disease. AIDS (Lond.). 10:867-880.

41. Danner, S.A., A. Carr, J.M. Leonard, L.M. Lehman, F. Gudiol, J. Gonzales, A. Raventos, R. Rubio, E. Bouza, V. Pintado, et al. 1995. A shortterm study of the safety, pharmacokinetics, and efficacy of Ritonavir, an inhibitor of HIV-1 protease. N. Engl. J. Med. 333:1528-1533.

42. Koot, M., A.B. Van 't Wout, N.A. Kootstra, R.E.Y. De Goede, M. Tersmette, and H. Schuitemaker. 1996. Relation between changes in cellular load, evolution of viral phenotype, and the clonal composition of virus populations in the course of human immunodeficiency virus type 1 infection. J. Infect. Dis. 173: 349-354.

43. Schnittman, S.M., H.C. Lane, J. Greenhouse, J.S. Justement, M Baseler, and A.S. Fauci. 1990. Preferential infection of $\mathrm{CD}^{+}$memory T cells by human immunodeficiency virus type 1: evidence for a role in the selective T-cell functional defects observed in infected individuals. Proc. Natl. Acad. Sci. USA. 87:6058-6062.

44. Mulder, J., N. McKinney, C. Christopherson, J. Sninsky, L. Greenfield, and S. Kwok. 1994. A rapid and simple PCR assay for quantification of human immunodeficiency virus type-1 RNA in plasma; application to acute retroviral infection. J. Clin. Microbiol. 32:292-300.

45. van Gemen, B., R. van Beuningen, A. Nabbe, D. Van Strijp, S. Jurriaans, P. Lens, and T. Kievits. 1994. A one-tube quantitative HIV-1 RNA NASBA nucleic acid amplification assay using electrochemiluminescent (ECL) labelled probes. J. Virol. Methods. 49:157-168.

46. Richman, D.D. 1995. Drug resistance in relation to pathogenesis. AIDS 9(suppl):S49-S53

47. Mueller, B.U., K.M. Butler, V.L. Stocker, F.M. Balis, P. Brouwers, P. Jarosinski, R.N. Husson, L.L. Lewis, D. Venzon, and P.A. Pizzo. 1994. Clinical and pharmacokinetic evaluation of long-term therapy with didanosine in children with HIV infection. Pediatrics. 94:724-731.

48. D'Aquila, R.T., V.A. Johnson, S.L. Welles, A.J. Japour, D.R. Kuritzkes, V. DeGruttola, P.S. Reichelderfer, R.W. Coombs, C.S. Crumpacker, J.O Kahn, D.D. Richman, for the AIDS Clinical Trials Group Protocol 116B/117 Team, and the Virology Committee Resistance Working Group. 1995. Zidovudine resistance and HIV-1 disease progression during antiretroviral therapy. Ann. Intern. Med. 122:401-408.

49. St. Clair, M.H., J.L. Martin, G. Tudor-Williams, M.C. Bach, C.L. Vavro, D.M. King, P. Kellam, S.D. Kemp, and B.A. Larder. 1991. Resistance to dd and sensitivity to AZT induced by a mutation in HIV-1 reverse transcriptase. Science (Wash. DC). 253:1557-1559.

50. Nielsen, C., L. Bruun, L.R. Mathiesen, C. Pedersen, and J. Gerstoft. 1996. Development of resistance to zidovudine (ZDV) and didanosine (ddI) in HIV from patients in ZDV, ddI and alternating ZDV/ddI therapy. AIDS (Lond.). 10:625-633.

51. Gao, W.Y., T. Shirasaka, D.G. Johns, S. Broder, and H. Mitsuya. 1993. Differential phosphorylation of azidothymidine, dideoxycytidine, and dideoxyinosine in resting and activated peripheral blood mononuclear cells. J. Clin. Invest. 91:2326-2333.

52. Gao, W.Y., R. Agbaria, J.S. Driscoll, and H. Mitsuya. 1994. Divergen anti-human immunodeficiency virus activity and anabolic phosphorylation of $2^{\prime}, 3^{\prime}$-dideoxynucleoside analogs in resting and activated human cells. J. Biol. Chem. 269:12633-12638.

53. Shirasaka, T., S. Chokekijchai, A. Yamada, G. Gosselin, J.-L. Imbach, and H. Mitsuya. 1995. Comparative analysis of anti-human immunodeficiency virus type 1 activities of dideoxynucleoside analogs in resting and activated peripheral blood mononuclear cells. Antimicrob. Agents Chemother. 39:25552559

54. Trkola, A., T. Dragic, J. Arthos, J.M. Binley, W.C. Olson, G.P. Allaway, C. Cheng-Mayer, J. Robinson, P.J. Maddon, and J.P. Moore. 1996. CD4-dependent, antibody-sensitive interactions between HIV-1 and its co-receptor CCR-5. Nature (Lond.). 384:184-187.

55. Bleul, C.C., L. Wu, J.A. Hoxie, T.A. Springer, and C.R. Mackay. 1997. The HIV coreceptor CXCR4 and CCR5 are differentially expressed and regulated on human T lymphocytes. Proc. Natl. Acad. Sci. USA. 94:1925-1930. 